\title{
Obstructive hydrocephalus due to cavernous dilation of Virchow-Robin spaces
}

\section{Figure MRI}
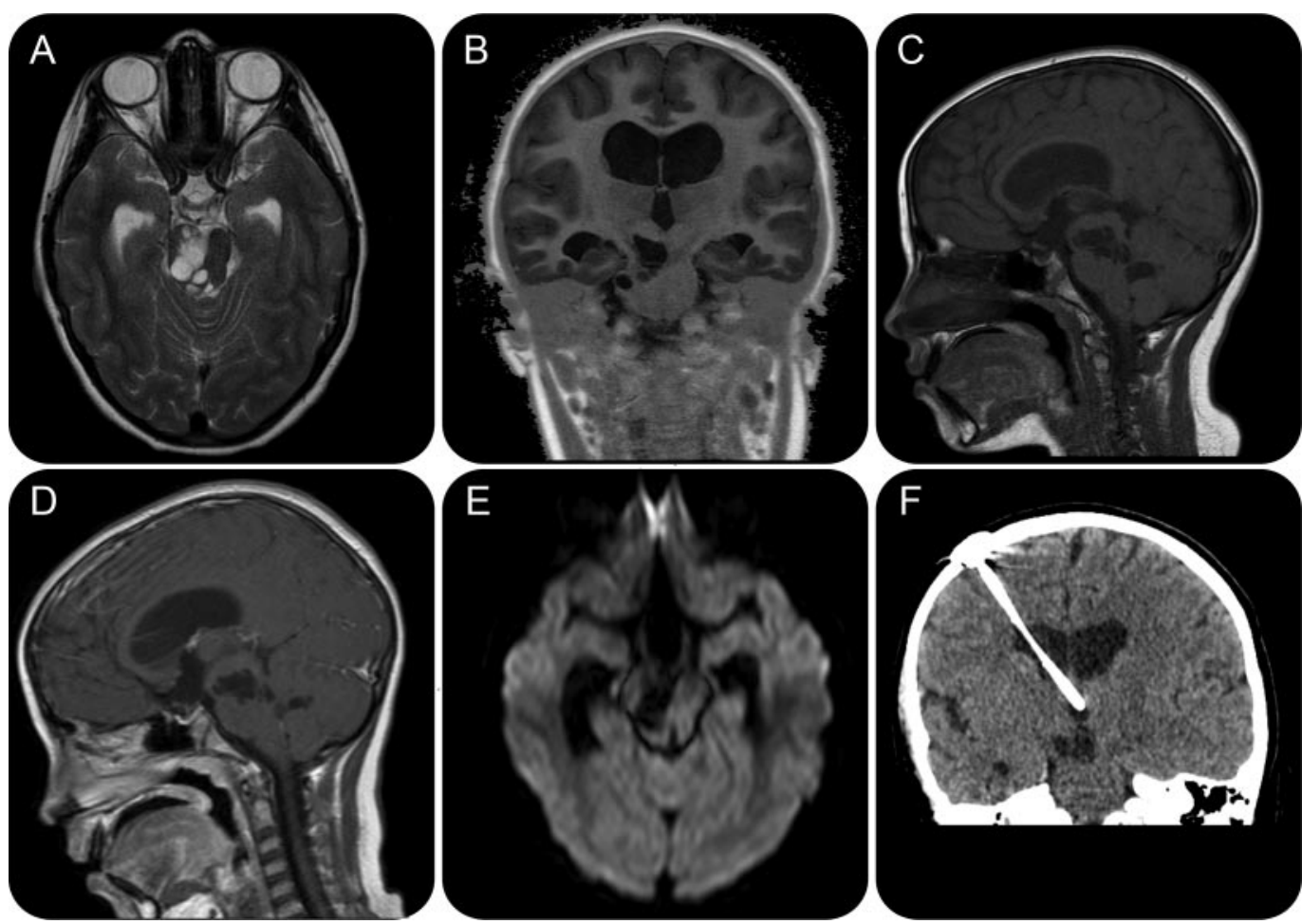

(A-E) Axial T2, coronal fluid-attenuated inversion recovery, sagittal T1 precontrast and postcontrast, and diffusionweighted MRI show multiple and confluent cyst-like lesions in the right thalamo-mesencephalic region isointense to CSF, causing obliteration of the aqueduct and no diffusion restriction. (F) Coronal CT reconstruction after ventriculoperitoneal shunt with resolution of hydrocephalus.

A 10-year-old girl presented with a 4-month history of headache and with a normal examination. MRI showed a multi-cyst mesencephalic lesion isointense relative to CSF on all sequences; there was mass effect on the aqueduct with obstructive hydrocephalus (figure). Infections, tumors, and epidermoid cyst were considered, but the characteristic location along the path of a penetrating vessel and magnetic resonance appearance is virtually pathognomonic of cavernous dilation of Virchow-Robin spaces. ${ }^{1,2}$ She received a ventriculoperitoneal shunt with prompt improvement of the headache and the hydrocephalus. Clinical and imaging follow-up examinations revealed no change.

\section{Flors, MD, C. Leiva-Salinas, MD, G. Cabrera, MD, M. Mazón, MD, C. Poyatos, MD, Valencia, Spain}

Disclosure: The authors report no disclosures.

Address correspondence and reprint requests to Dr. Lucia Flors, Department of Radiology, Hospital Universitario Doctor Peset, Gaspar Aguilar 90, 46017 Valencia, Spain; flors_luc@gva.es

1. Salzman KL, Osborn AG, House P, et al. Giant tumefactive perivascular spaces. AJNR Am J Neuroradiol 2005;26:298-305.

2. Papayannis CE, Saidon P, Rugilo CA, et al. Expanding Virchow-Robin spaces in the midbrain causing hydrocephalus. AJNR Am J Neuroradiol 2003;24:1399-1403. 


\section{Neurology}

Obstructive hydrocephalus due to cavernous dilation of Virchow-Robin spaces

L. Flors, C. Leiva-Salinas, G. Cabrera, et al.

Neurology 2010;74;1746

DOI 10.1212/WNL.0b013e3181e04312

This information is current as of May 24, 2010

\section{Updated Information \&} Services

References

Subspecialty Collections

Permissions \& Licensing

Reprints including high resolution figures, can be found at: http://n.neurology.org/content/74/21/1746.full

This article cites 2 articles, 0 of which you can access for free at: http://n.neurology.org/content/74/21/1746.full\#ref-list-1

This article, along with others on similar topics, appears in the following collection(s):

Hydrocephalus

http://n.neurology.org/cgi/collection/hydrocephalus

MRI

http://n.neurology.org/cgi/collection/mri

Pediatric headache

http://n.neurology.org/cgi/collection/pediatric_headache

Secondary headache disorders

http://n.neurology.org/cgi/collection/secondary_headache_disorders

Information about reproducing this article in parts (figures,tables) or in its entirety can be found online at:

http://www.neurology.org/about/about_the_journal\#permissions

Information about ordering reprints can be found online:

http://n.neurology.org/subscribers/advertise

Neurology ${ }^{\circledR}$ is the official journal of the American Academy of Neurology. Published continuously since 1951, it is now a weekly with 48 issues per year. Copyright . All rights reserved. Print ISSN: 0028-3878. Online ISSN: 1526-632X.

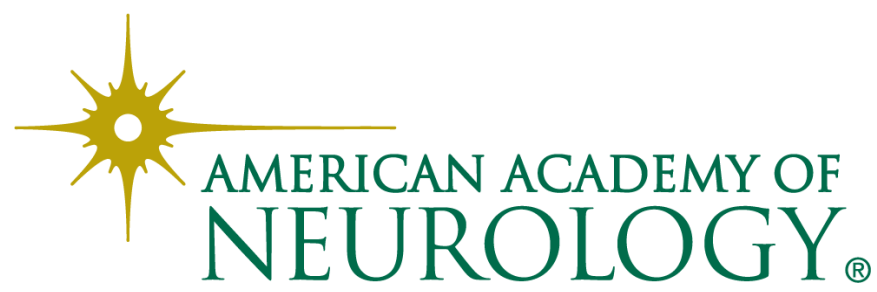

